\title{
Notes on crabs of the families Goneplacidae and Dorippidae (Decapoda: Brachyura) from the Dampier Archipelago, Western Australia
}

\author{
Brent P. Thoma* \\ The University of Southern Mississippi, Department of Coastal Sciences, \\ PO Box 7000 Ocean Springs, Mississippi 39566-7000, U.S.A. \\ * Present address: University of Louisiana at Lafayette, PO Box 42451, Lafayette, Louisiana 70504, U.S.A. \\ email: Brent.Thoma@louisiana.edu
}

\begin{abstract}
Nineteen specimens representing four species in the brachyuran families Goneplacidae and Dorippidae were collected during a four year biological survey of the Dampier Archipelago, in northwest Western Australia, conducted by the Western Australia Museum. Two of the species are goneplacids, Eucrate affinis and E. dorsalis and the other two are dorippids, Dorippe quadridens and Paradorippe australiensis. Notes on range extensions, habitats, etc., are provided for these four species.
\end{abstract}

\section{INTRODUCTION}

The knowledge of the marine fauna of the Dampier Archipelago, on the northwest coast of Western Australia, remains incomplete. To increase our understanding of the fauna of the Dampier Archipelago, the Western Australian Museum conducted a four-year marine biological survey of the marine flora and fauna from the waters of the Dampier Archipelago. The survey consisted of a series of marine expeditions - two diving surveys (October 1998 and September 1999), a dredging and trawling expedition (July 1999), mangrove fieldwork, and a marine biological workshop (August 2000). Herein, I report on the crabs of the families Goneplacidae and Dorippidae collected as a part of this survey. Notes on range extensions, habitats, etc. are provided for four species.

The family Goneplacidae has long been a heterogeneous grouping for species that did not conveniently fit the diagnosis of another family. Guinot (1969a, b, c; 1971) made the most significant steps in clarifying the phylogenetic relationships of the Goneplacidae. Although she recognized six separate groups within the Goneplacidae, she did not formalize any of these groups nomenclaturally. $\mathrm{Ng}$ (1987) was the first to formally remove any of the lineages that were recognized by Guinot when he transferred the subfamily Rhizopinae from the Goneplacidae to the Pilumnidae. In 1986, Guinot recognized the subfamily Trogloplacinae for the monotypic genus Trogloplax Guinot, 1986; however, Davie (2002) later elevated the Trogloplacinae to full family status. Serene (1984) recognized a new subfamily, Planopilumninae, in the Pilumnidae, which was later regarded as a goneplacid taxon (see Ng and Clark, 2000a, b; Ng et al., 2001). In 1994, Ng and Wang resurrected the subfamily Pseudoziinae Alcock, 1898, within the
Goneplacidae for the genus Pseudozius Dana, 1851. Subsequently, $\mathrm{Ng}$ and Liao (2002) recognised the Pseudoziinae as a full family which encompasses the subfamilies Pseudoziinae and Planopilumninae. More recently, there has been growing evidence supporting the elevation of the Euryplacinae, Carcinoplacinae, and Chasmocarcininae to full family status (see D'Udekem d'Acoz, 1999; Karasawa and Kato, 2003; Števčič, 2005; Karasawa and Schweitzer, 2006 for discussion); however, until additional support is provided for the elevation of these three subfamilies, I recognize the Goneplacidae as containing four subfamilies: Goneplacinae, Carcinoplacinae, Euryplacinae, and Chasmocarcininae. This manuscript includes the Goneplacidae as defined above.

\section{MATERIALS AND METHODS}

A complete synonymy for each species or complete references to all original species descriptions are not presented. Abbreviations used in this manuscript include: meters $(\mathrm{m})$, carapace length $(\mathrm{cl})$, carapace width (cw) and ovigerous (ovig.). Measurements are given in millimeters (mm). All materials examined have been deposited at the Western Australian Museum (WAM), Perth, Western Australia.

\section{SYSTEMATIC ACCOUNT}

Family Goneplacidae MacLeay, 1838

Subfamily Euryplacinae Stimpson, 1871

Eucrate De Haan, 1835

Eucrate affinis Haswell, 1881

For synonymies prior to 1969, see Campbell (1969). 


\section{Material examined}

Western Australia, Dampier Archipelago. WAM C 27063 (1 male, cw $4.0 \mathrm{~mm}$, cl $3.1 \mathrm{~mm}$ ), stn DA2/99/ 94, $0.6 \mathrm{n}$. mls SE of King Pt, East Lewis I. $\left(20^{\circ} 38.37^{\prime} \mathrm{S}, 116^{\circ} 38.41^{\prime} \mathrm{E}\right.$ to $\left.20^{\circ} 38.39^{\prime} \mathrm{S}, 116^{\circ} 38.52^{\prime} \mathrm{E}\right)$, fine mesh scoop box dredge, 14.5-16.0 m, 27.07.1999; WAM C 25429 (1 male, cW $5.85 \mathrm{~mm}$, cl $4.80 \mathrm{~mm}$ ), stn DA2/99/38, $2.1 \mathrm{n}$. mls WSW of Marks Pt, West Lewis I. $\left(20^{\circ} 37.47^{\prime} \mathrm{S}, 116^{\circ} 35.37^{\prime} \mathrm{E}\right.$ to $20^{\circ} 36.91^{\prime} \mathrm{S}$, $\left.116^{\circ} 35.33^{\prime} \mathrm{E}\right)$, rake box dredge,11.0-13.0 m,19.07.1999; WAM C 27107 (1 male, cw $7.80 \mathrm{~mm}$, cl $6.25 \mathrm{~mm}$ ), stn DA2/99/99 $1.05 \mathrm{n}$. mls WSW of Rocky Head, Enderby I. (20'37.36'S, $116^{\circ} 26.85^{\prime} \mathrm{E}$ to $20^{\circ} 37.02^{\prime} \mathrm{S}$, $\left.116^{\circ} 26.44^{\prime} \mathrm{E}\right)$, rake box dredge, $17.0-19.0 \mathrm{~m}$, 28.07.1999; WAM C 27105 (1 male, cw 9.6 mm, cl 7.3 $\mathrm{mm})$, stn DA2/99/29, 4.35 n. mls $W$ of Cape Bruguieres $\left(20^{\circ} 24.64^{\prime} \mathrm{S}, 116^{\circ} 44.05^{\prime} \mathrm{E}\right.$ to $20^{\circ} 24.76^{\prime} \mathrm{S}$, $\left.116^{\circ} 43.65^{\prime} \mathrm{E}\right)$, rake box dredge, $27.0-28.0 \mathrm{~m}$, 17.07.1999; WAM C 27087 (1 non-ovig. female, cw $8.5 \mathrm{~mm}, \mathrm{cl} 6.7 \mathrm{~mm}$ ), stn DA2/99/57, $1.05 \mathrm{n}$. $\mathrm{mls} \mathrm{N}$ of Roly Rock $\left(20^{\circ} 29.03^{\prime} \mathrm{S}, 116^{\circ} 30.45^{\prime} \mathrm{E}\right.$ to $20^{\circ} 29.18^{\prime} \mathrm{S}$, $\left.116^{\circ} 30.06^{\prime} \mathrm{E}\right)$, rake box dredge, $32-33 \mathrm{~m}, 21.07 .1999$; WAM C 27054 (1 non-ovig. female, cw $8.9 \mathrm{~mm}$, cl 6.7 $\mathrm{mm}), \operatorname{stn} \mathrm{DA} 2 / 99 / 81, \sim 2.35 \mathrm{n}$. mls $\mathrm{N}$ of $\mathrm{W}$ point of Kendrew I. $\left(20^{\circ} 26.51^{\prime} \mathrm{S}, 116^{\circ} 31.57^{\prime} \mathrm{E}\right.$ to $20^{\circ} 26.37^{\prime} \mathrm{S}$, $\left.116^{\circ} 31.73^{\prime} \mathrm{E}\right)$, rake box dredge, $38 \mathrm{~m}, 25.07 .1999$; WAM C 27093 (1 non-ovig. female, cw $9.9 \mathrm{~mm}$, cl 8.0 $\mathrm{mm}$ ), stn DA2/99/65, 2.4 n. mls NW of light on East Intercourse I. (20³8.31'S, $116^{\circ} 38.46^{\prime} \mathrm{E}$ to $20^{\circ} 38.77^{\prime} \mathrm{S}$, $\left.116^{\circ} 38.54 ' \mathrm{E}\right)$, rake box dredge, $10-15 \mathrm{~m}, 23.07 .1999$; WAM C 27088 (1 non-ovig. female [carapace damaged]), stn DA2/99/58, 1 n. ml NNE of Roly Rock $\left(20^{\circ} 29.11^{\prime} \mathrm{S}, 116^{\circ} 30.78^{\prime} \mathrm{E}\right.$ to $20^{\circ} 29.35^{\prime} \mathrm{S}$, $\left.116^{\circ} 30.55^{\prime} \mathrm{E}\right)$, rake box dredge, $25-25.5 \mathrm{~m}, 21.07 .1999$.

\section{Remarks}

The specimens examined generally agree with the diagnosis given by Campbell (1969). However, the median carinae of the third and fourth teeth of the anterolateral margins are slightly weaker than those described by Campbell (1969).

\section{Distribution}

Limited to the coastal waters of Australia, Port Denison (type locality, Haswell, 1881) (New South Wales), Port Molle (Miers, 1884) (Queensland); Dampier Archipelago (Western Australia).

\section{Habitat}

Sublittoral, in depths of 10 to $40 \mathrm{~m}$; substrate sandy mud with rocks interspersed to coarse shelly gravel with rocks.

\section{Eucrate dorsalis (White, 1849)}

For synonymies prior to 1969, see Campbell (1969).

\section{Material examined}

Western Australia, Dampier Archipelago. WAM
C 27104 ( 1 male, cw $9.3 \mathrm{~mm}, \mathrm{cl} 11.8 \mathrm{~mm}$ ), stn DA2/ 99/17, 3 n. mls ESE of Sloping Pt, Burrup Pen. $\left(20^{\circ} 32.99^{\prime} \mathrm{S}, 116^{\circ} 54.71^{\prime} \mathrm{E}\right.$ to $\left.20^{\circ} 33.47^{\prime} \mathrm{S} 116^{\circ} 54.97^{\prime} \mathrm{E}\right)$, rake box dredge, $16.5-17.0 \mathrm{~m}, 16.07 .1999$; WAM C 27106 (1 male, cW $6.5 \mathrm{~mm}$, cl $8.0 \mathrm{~mm}$ ), stn DA2/99/ $64, \sim 2$ n. mls $\mathrm{N}$ of light on East Intercourse I. $\left(20^{\circ} 37.43^{\prime} \mathrm{S}, 116^{\circ} 40.77^{\prime} \mathrm{E}\right.$ to $\left.20^{\circ} 37.79^{\prime} \mathrm{S}, 116^{\circ} 40.76^{\prime} \mathrm{E}\right)$, rake box dredge, $12.0-14.0 \mathrm{~m}, 23.07 .1999$.

\section{Remarks}

The diagnostic large red spot in the center of the carapace as noted by Campbell (1969) is visible even in alcohol preserved specimens.

\section{Distribution}

Limited to the coastal waters of Australia; Moreton Bay (Brisbane) to Gulf of Carpentaria (Campbell, 1969) (Queensland); Dampier Archipelago (Western Australia).

\section{Habitat}

Sublittoral, in depths of 10 to $20 \mathrm{~m}$; substrate mud to mud with rubble and small gravel.

\section{Family Dorippidae MacLeay, 1838}

Subfamily Dorippinae MacLeay, 1838

\section{Dorippe Weber, 1795}

\section{Dorippe quadridens (Fabricius, 1793)}

For complete synonymy prior to 1990 , see Holthuis and Manning (1990).

\section{Material examined}

Western Australia, Dampier Archipelago. WAM C 27117 (1 male, cw $5.1 \mathrm{~mm}$, cl $5.5 \mathrm{~mm}$ ), stn DA2/ 99/11, 5.9 n. mis NNW of NW point of Delambre I. $\left(20^{\circ} 20.75^{\prime} \mathrm{S}, 117^{\circ} 01.16^{\prime} \mathrm{E}\right.$ to $\left.20^{\circ} 20.19^{\prime} \mathrm{S}, 117^{\circ} 01.18^{\prime} \mathrm{E}\right)$, rake box dredge, 32.0-34.0 m, 15.07.1999; WAM C 27124 (1 male, cw $7.2 \mathrm{~mm}, \mathrm{cl} 7.0 \mathrm{~mm}$ ), stn DA2/99/ 91, 1.4 n. mls ESE of Tish Point, Rosemary I. (2030.48'S, $116^{\circ} 36.53^{\prime} \mathrm{E}$ to $\left.20^{\circ} 30.27^{\prime} \mathrm{S}, 116^{\circ} 36.86^{\prime} \mathrm{E}\right)$, rake box dredge, $9.0-10.0 \mathrm{~m}, 26.07 .1999$; WAM C 27120 (1 male, cw $7.3 \mathrm{~mm}, \mathrm{cl} 7.4 \mathrm{~mm}$ ), stn DA2/99/ 46, 2.4 n. mls WNW of Rocky Head, Enderby I. ( $20^{\circ} 35.90^{\prime} \mathrm{S}, 116^{\circ} 24.60^{\prime} \mathrm{E}$ to $\left.20^{\circ} 35.48^{\prime} \mathrm{S}, 116^{\circ} 25.52^{\prime} \mathrm{E}\right)$, rake box dredge, $17.5-18.0 \mathrm{~m}$; 20.07.1999; WAM C 27121 ( 1 male, cw $10.1 \mathrm{~mm}$, cl $10.5 \mathrm{~mm}$ ), stn DA2/ 99/62, Flying Foam Passage, 0.9 n. mls NE of $S$ tip of Angel I. $\left(20^{\circ} 30.69^{\prime} \mathrm{S}, 116^{\circ} 48.58^{\prime} \mathrm{E}\right.$ to $20^{\circ} 31.17^{\prime} \mathrm{S}$, $\left.116^{\circ} 48.33^{\prime} \mathrm{E}\right)$, rake box dredge, $7.0-9.0 \mathrm{~m}, 22.07 .1999$; WAM C 27123 ( 1 male, cW $15.0 \mathrm{~mm}$, cl $16.6 \mathrm{~mm}$ ), stn DA2/99/74, 1.95 n. mls SE of Rocky Head, Enderby I. (2038.34'S, $116^{\circ} 29.18^{\prime} \mathrm{E}$ to $20^{\circ} 38.83^{\prime} \mathrm{S}$, $\left.116^{\circ} 28.85^{\prime} \mathrm{E}\right)$, rake box dredge, $10.5-11.5 \mathrm{~m}$, 24.07.1999; WAM C 27118 (1 female, cw $18.5 \mathrm{~mm}, \mathrm{cl}$ $18.7 \mathrm{~mm}), \operatorname{stn} \mathrm{DA} 2 / 99 / 25, \sim 5.2 \mathrm{n}$. mls $\mathrm{N}$ of 
Rosemary I. $\left(20^{\circ} 22.29^{\prime} \mathrm{S}, 116^{\circ} 35.56^{\prime} \mathrm{E}\right.$ to $20^{\circ} 22.62^{\prime} \mathrm{S}$, $\left.116^{\circ} 35.44^{\prime} \mathrm{E}\right)$, rake box dredge, $39.0 \mathrm{~m}, 17.07 .1999$; WAM C 27122 ( 1 female, cw $28.0 \mathrm{~mm}$, cl $27.5 \mathrm{~mm}$ ), stn DA2/99/73, 3.25 n. mls S of Rocky Head, Enderby I. $\left(20^{\circ} 40.14^{\prime} \mathrm{S}, 116^{\circ} 27.69^{\prime} \mathrm{E}\right.$ to $20^{\circ} 39.93^{\prime} \mathrm{E}$, $\left.116^{\circ} 27.96 \mathrm{E}\right)$, rake box dredge, $12.5 \mathrm{~m}, 24.07 .1999$.

\section{Distribution}

Holthuis and Manning (1990) reported this species from throughout the Indo-West Pacific. Within the coastal waters of Australia, it occurs from Moreton Bay (Queensland) northward and westward to Shark Bay (Western Australia), interrupted by an apparent gap in the northern extremes of Australia (Holthuis and Manning 1990). For more details, see Manning and Holthuis (1990).

\section{Habitat}

Sublittoral, shallow water, in depths of 7 to $39 \mathrm{~m}$ in the current study; substrate shelly sand or mud to sand and rocks. Holthuis and Manning (1990) reported that this species most commonly occurs in depths of 1 to $30 \mathrm{~m}$, on soft mud or sand/mud bottoms.

\section{Paradorippe Serène and Romimohtarto, 1969}

\section{Paradorippe australiensis (Miers, 1884)}

For complete synonymy prior to 1990, see Holthuis and Manning (1990).

\section{Material examined}

Western Australia, Dampier Archipelago. WAM C 27119 (1 immature, cw $8.4 \mathrm{~mm}$, cl $8.3 \mathrm{~mm}$ ), stn DA2/99/36, 4.0 n. mls WSW of High Pt, on island $\mathrm{NE}$ of West Lewis I. $\left(20^{\circ} 33.58^{\prime} \mathrm{S}, 116^{\circ} 36.87^{\prime} \mathrm{E}\right.$ to $20^{\circ} 33.88^{\prime} \mathrm{S}, 116^{\circ} 36.25^{\prime} \mathrm{E}$ ), rake box dredge, $13 \mathrm{~m}$, 19.07.1999; WAM C 26230 ( 1 female, cW $11.4 \mathrm{~mm}, \mathrm{cl}$ $10.9 \mathrm{~mm})$, stn DA2/99/59, $1.8 \mathrm{n}$. mls $\mathrm{S}$ of Courtenay Head Light, Malus I. (20³2.23'S, $116^{\circ} 41.63^{\prime} \mathrm{E}$ to $20^{\circ} 32.09^{\prime} \mathrm{S}, 116^{\circ} 41.16^{\prime} \mathrm{E}$ ), rake box dredge, 17.0-19.0 m, 22.07.1999.

\section{Distribution}

Moreton Bay (Queensland) northward and westward to Garden. Island (Western Australia), interrupted by a gap in the northern extremes of Australia. Davie (2002) reported this species from Irian Jaya.

\section{Habitat}

Sublittoral, shallow water, in depths of 13 to $19 \mathrm{~m}$ in the current study; substrate shelly mud with rocks. Holthuis and Manning (1990) reported this species from depths of up to $22 \mathrm{~m}$, on a variety of substrates including reef flats, mud, and sand substrata.

\section{ACKNOWLEDGEMENTS}

Thanks are extended to R.W. Heard for his support and guidance during this project; and, to J.M. Foster, S.E. LeCroy and J.N. Thoma, whose tireless counsel greatly improved the quality of this manuscript. I am also grateful to J. Shaw, M. Williams and C. Schloss of the Gunter Library, Gulf Coast Research Laboratory, for their assistance in gathering sources. Partial funding for this research was provided through NSF Award 9912324, The University of Southern Mississippi, Jackson State University Research Experience in Coastal and Marine Science Program.

\section{REFERENCES}

Campbell, B.M. (1969). The genus Eucrate (Crustacea: Goneplacidae) in eastern Australia and the Indo-west Pacific. Memoirs of the Queensland Museum 15: 117140.

Dana, J.D. (1851). On the Classification of the Cancroidea. American Journal of Sciences and Arts (2)12: 121-131.

Davie, P.J.F. (2002). Crustacea: Malacostraca: Eucarida (Part 2): Decapoda - Anomura, Brachyura. In Wells, A. \& Houston, W.W.K. (eds), Zoological Catalogue of Australia 19.3B Melbourne: CSIRO Publishing, Australia. pp.xiv +641 .

De Haan, W. (1835). Crustacea. pp. 1-243 pls A-J, L-Q, 1-55, circ. tảb. 2 In Von Siebold, P.F. Fauna Japonica Sive Descriptio Animalium, quae in Itinere per Japoniam, Jussu et Auspiciis Superiorum, qui Summum in India Batava Imperium Tentent, Suscepto, Annis 1823-1830 collegit, Notis, Observationibus et Adumbrationibus Illustravit. Leiden: Lugundi-Batavorum.

D'Udekem d'Acoz, C. (1999). Inventaire et distribution des crustacés décapodes de l'Atlantique nordoriental, de la Méditerranée et des eaux continentales adjacentes au nord de $25^{\circ} \mathrm{N}$. Patrimoines naturels (M.N.H.N./S.P.N.) 40: 1-383.

Fabricius, J.C. (1793). Entomologia systematica emendata et aucta, Secundum classes, ordines, genera, species, adjectis synonimis, locis, observationibus, descriptionibus. Hafniae, impensis C.G. Proft, Vol. 2, viii +519 pp.

Guinot, D. (1969a). Recherches préliminaries sur les groupements naturels chez les Crustacés Décapodes Brachyoures. VII. Les Goneplacidae. Bulletin $d u$ Muséum national d'Histoire naturelle, Paris (2) 41: 241-265.

Guinot, D. (1969b). Recherches préliminaries sur les groupements naturels chez les Crustacés Décapodes Brachyoures VII. Les Goneplacidae (suite). Bulletin du Muséum national d'Histoire naturelle, Paris (2)41: 507-528.

Guinot, D. (1969c). Recherches préliminaries sur les groupements naturels chez les Crustacés Décapodes Brachyoures. VII. Les Goneplacidae (suite et fin). Bulletin du Muséum national d'Histoire naturelle, Paris (2)41: 688-724.

Guinot, D. (1971). Recherches préliminaries sur les 
groupements naturels chez les Crustacés Décapodes Brachyoures. VIII. Synthèse et bibliographie. Bulletin du Muséum national d'Histoire naturelle, Paris (2)42: 1063-1090.

Guinot, D. (1986). Description d'un Crabe cavernicole aveugle de Nouvelle-Bretagne (Papouasie NouvelleGuinée), Trogloplax joliveti gen. nov. sp. nov., et établissement $d$ 'une sous-famille nouvelle, Trogloplacinae subfam.nov. Comptes Rendus des Séances de l'Academie des Sciences (3)303: 307-312.

Haswell, W.A. (1881). On some new species of Australian Brachyura. Proceedings of the Linnean Society of New South Wales 6: 540-551.

Holthuis, L.B. and Manning, R.B. (1990). Crabs of the subfamily Dorippinae MacLeay, 1838, from the IndoWest Pacific region (Crustacea: Decapoda: Dorippidae). Researches on Crustacea, Special Number 3: 1-151.

Karasawa, H. and Kato, H. (2003). The family Goneplacidae MacLeay, 1838 (Crustacea: Decapoda: Brachyura): systematics, phylogeny, and fossil records. Paleontological Research 7: 129-151.

Karasawa, H. and Schweitzer, C.E. (2006). A new classification of the Xanthoidea sensu lato (Crustacea: Decapoda: Brachyura) based on phylogenetic analysis and traditional systematics and evaluation of all fossil Xanthoidea sensu lato. Contributions to Zoology 75: 23-72.

MacLeay, W.S. (1838). On the Brachyurous Decapod Crustacea brought from the Cape by Dr. Smith: pp 53-71, pl. 3. In: Illustrations of the Annulosa of South Africa; being a portion of the objects of natural history chiefly collected during an expedition into the interior of South Africa, under the direction of Dr. Andrew Smith, in the years 1834, 1835, and 1836; fitted out by "The Cape of Good Hope Association for Exploring Central Africa". Smith, Elder and Company, London. 75 pp. 4 pls.

Miers, E.J. (1884). Crustacea. Report of the Zoological Collections made in the Indo-Pacific during the Voyage of H.M.S. 'Alert' 1881-2. Part I. The collections from Melanesia. Part II. Collections from the western Indian Ocean. London. British Museum. pp. 178-322, 513-575, pls 18-32, 46-51.

Ng, P.K.L. (1987). The Indo-Pacific Pilumnidae II. A revision of the genus Rhizopa Stimpson, 1858, and the status of the Rhizopinae Stimpson, 1858 (Crustacea, Decapoda, Brachyura). Indo-Malayan Zoology 4: 69-111.
Ng, P.K.L. and Clark, P.F. (2000a). The Indo-Pacific Pilumnidae XII. On the familial placement of Chlorodiella bidentata (Nobili, 1901) and Tanaocheles stenochilus Kropp, 1984 using adult and larval characters with the establishment of a new subfamily, Tanaochelinae (Crustacea: Decapoda: Brachyura). Journal of Natural History 34: 207-245.

Ng, P.K.L. and Clark, P.F. (2000b). The eumedonid file: a case study of systematic compatibility using larval and adult characters (Crustacea: Decapoda: Brachyura). Invertebrate Reproduction and Development 38: 225-252.

$\mathrm{Ng}$, P.K.L. and Liao, L.M. (2002): On a new species of Euryozius Miers, 1886 (Crustacea: Decapoda: Brachyura: Pseudoziidae) from the Philippines, with notes on the taxonomy of the genus. Proceedings of the Biological Society of Washington 115: 585-593.

Ng, P.K.L. and Wang, C.H. (1994). Notes on the enigmatic genus Pseudozius Dana, 1851 (Crustacea, Decapoda, Brachyura). Journal of the Taiwan Museum 47: 83-99.

Ng, P.K.L., Wang, C.-H., Ho, P.-H. and Shih, H.-T. (2001). An annotated checklist of brachyuran crabs from Taiwan (Crustacea, Decapoda). National Taiwan Museum Special Publication Series, Taipei, Taiwan 11: 1-86.

Serène, R. and Romimohtarto, K. (1969). Observations of the Species Dorippe from the Indo-Malayan Region. Marine Research in Indonesia [Penelitian laut di Indonesia] 9: 1-35.

Števčič, Z. (2005). The reclassification of brachyuran crabs (Crustacea: Decapoda: Brachyura). Fauna Croatica 14, supplement 1: $159 \mathrm{pp}$.

Stimpson, W. (1871). Preliminary report on the Crustacea dredged in the Gulf Stream in the Straits of Florida, by L. F. Pourtales. pt. 1. Brachyura. Bulletin of the Museum of Comparative Zoology at Harvard College 2: $109-160$.

Weber, F. (1795). Nomenclator entomologicus secundum entomologiam systematicus ill: Fabricii, adjectis, speciebus recens detectis et varietatibus. Chilonii, Hamburg. pp. viii +171 .

White, A. (1849). Description of two new species of Crustacea. Proceedings of the Zoological Society of London, 15: 144, pl. 6 [dated 1848, published 1849]. [Also published in The Annals and Magazine of Natural History, series 2, 4: 381-382, 1849]. 